\title{
Deep Lipoma
}

National Cancer Institute

\section{Source}

National Cancer Institute. Deep Lipoma. NCI Thesaurus. Code C6498.

A benign well-circumscribed tumor, composed of mature adipocytes, that arises within deep soft tissues. 